\title{
The Westernmost Mediterranean evolution: A review of the Alboran and Algero-Balearic basins stratigraphy
}

Laura Gómez de la Peña ${ }^{1,}{ }^{*}$, César Ranero ${ }^{1,2}$, Eulàlia Gràcia ${ }^{1}$, and Guillermo Booth-Rea ${ }^{3,4}$

${ }^{1}$ Barcelona Center for Subsurface Imaging, Institut de Ciències del Mar, CSIC, Barcelona, Spain

*Currently at: GEOMAR Helmholtz Centre for Ocean Research Kiel, Dynamics of the Ocean Floor, Kiel, Germany (Igomez@geomar.de)

2ICREA, Barcelona, Spain

${ }^{3}$ Instituto Andaluz de Ciencias de la Tierra, CSIC, Granada, Spain

${ }^{4}$ Facultad de Ciencias, Universidad de Granada, 18071 Granada, Spain

This work is currently under review: Gómez de la Peña, Ranero, Gràcia and Booth-Rea: The evolution of the westernmost Mediterranean basins. Submitted to "Earth-Science Reviews", 2020 
$\rightarrow$ Based on $\sim 4500 \mathrm{~km}$ of new and reprocessed multichannel seismic profiles (Fig. 1), together with well and dredge data (Fig. 1), we are able to review the westernmost Mediterranean stratigraphy at a regional scale.

$\rightarrow$ We have correlated the sediment units deposited since the beginning of the formation of the different sub-basins (including the Miocene emerged sub-basins onshore South Iberia, Fig. 1), and we present for the first time a coherent stratigraphy (Fig. 2) and large-scale tectonic evolution of the whole region.

$\rightarrow$ The results provide the information to test and refine models of the geodynamic evolution of the westernmost Mediterranean (Fig. 5). 


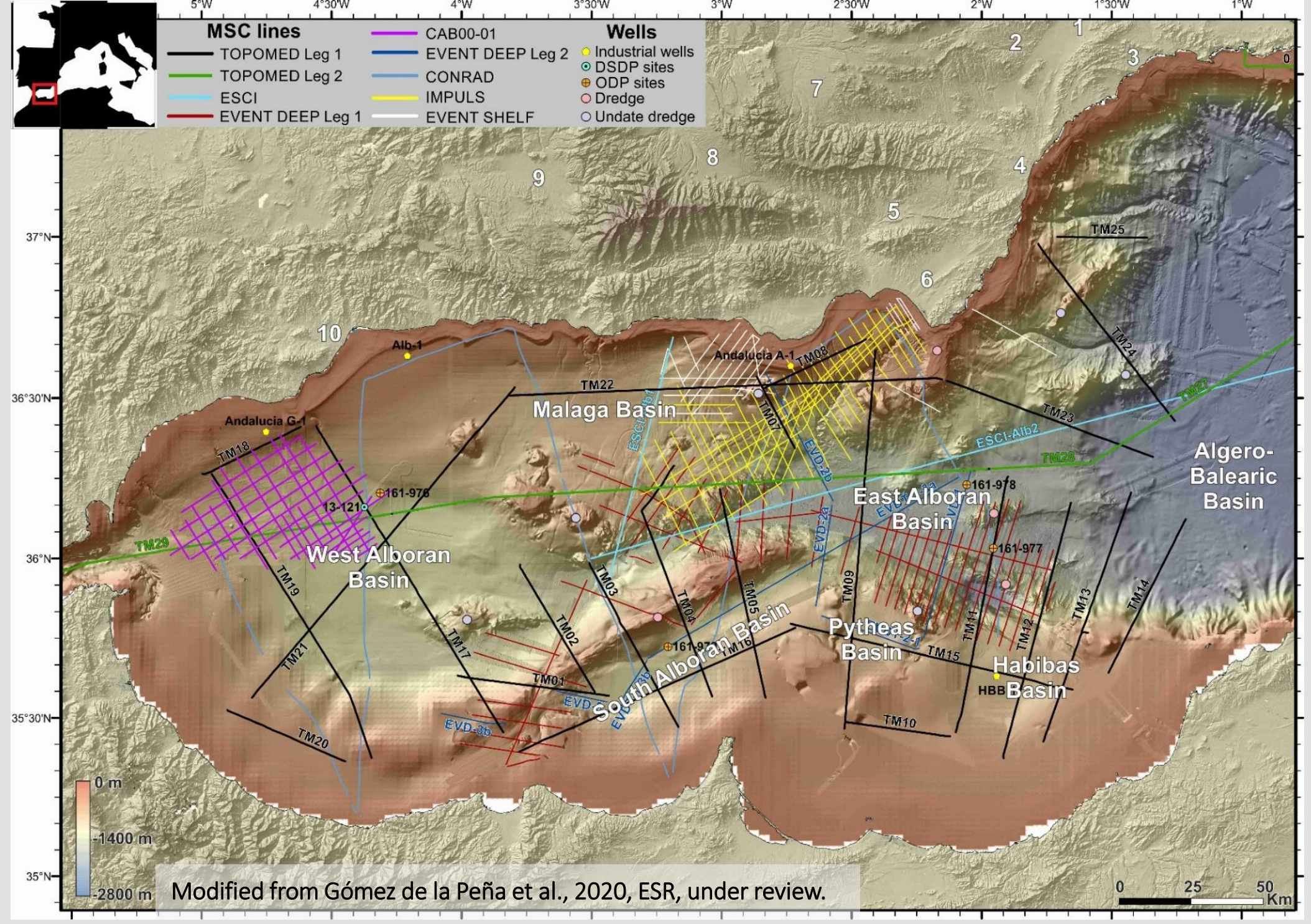

Figure 1: Bathymetric map of the Alboran Sea from digital grids released by SRTM-3, IEO bathymetry (Ballesteros et al., 2008, Gómez de la Peña et al., 2016), GEBCO compilation and data acquired during B-CSI cruises (Gràcia et al., 2006, 2012). Location of MCS profiles, commercial and scientific wells and dredges used in this study is shown (see map legend with the details). We integrated into the existing database a new grid of MCS profiles from the B-CSI: TOPOMED, EVENT-DEEP and ESCI. White numbers depicted the location of the main sedimentary depocentres onshore the Betics: 1: Fortuna Basin, 2: Lorca Basin, 3: Mazarrón Basin, 4: Vera Basin, 5: Tabernas-Sorbas Basins, 6: Níjar Basin, 7: Baza Basin, 8: Guadix Basin, 9: Granada Basin, 10: Málaga Basin. 


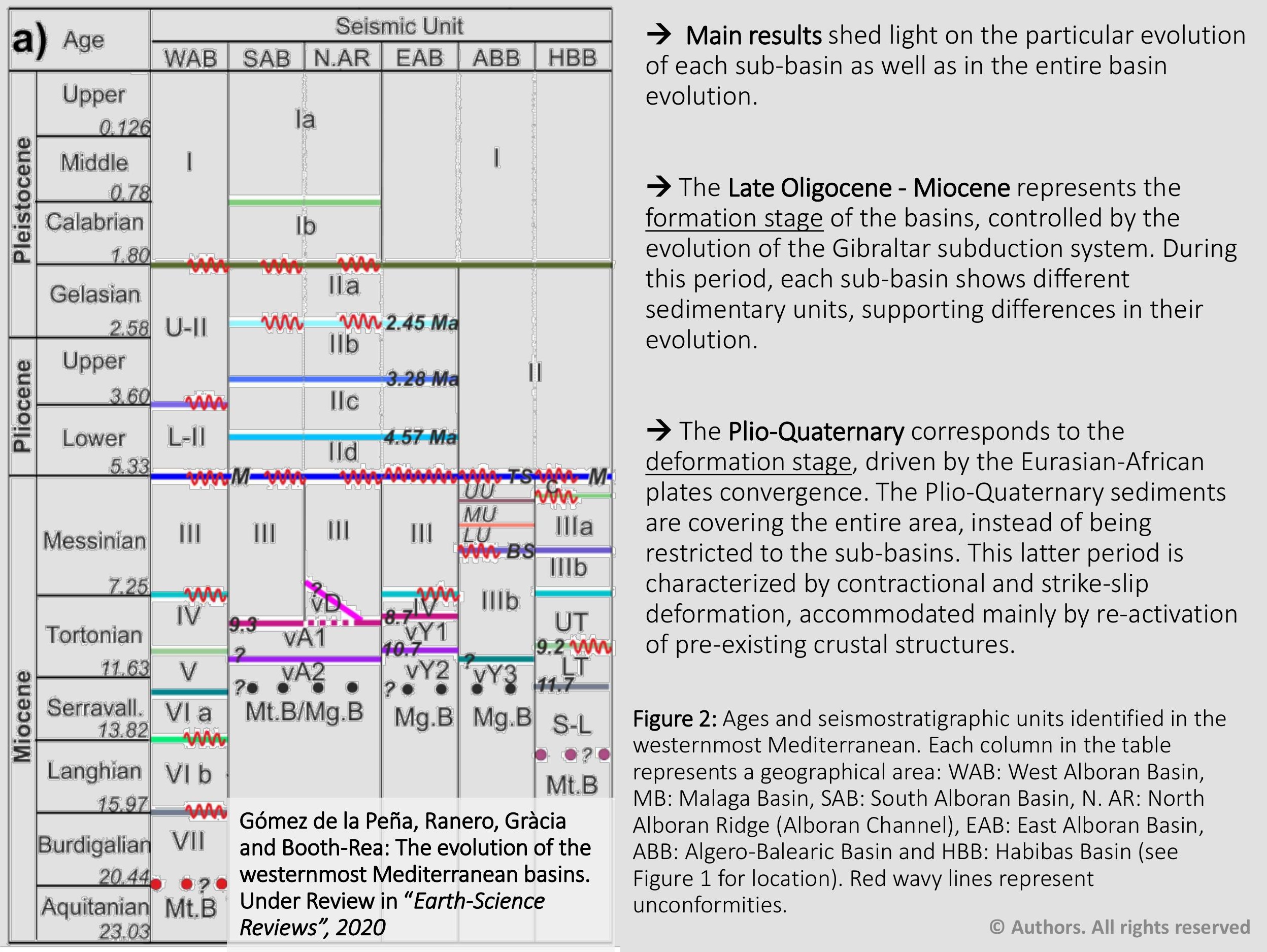




\section{Example of the TOPOMED MCS profiles: Malaga Basin}

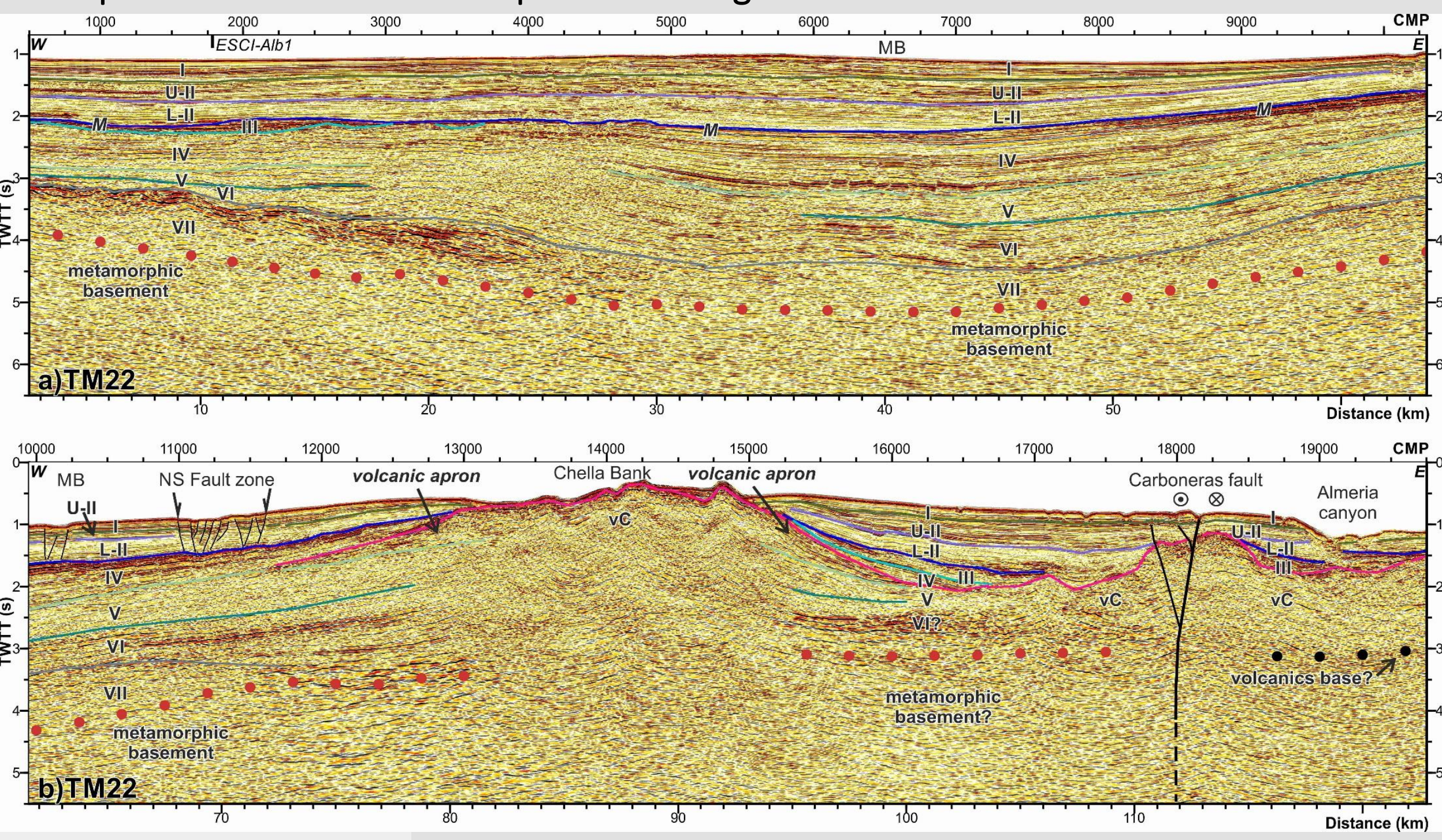

Gómez de la Peña, Ranero, Gràcia and Booth-Rea: The evolution of the westernmost Mediterranean basins. Under Review in "EarthScience Reviews", 2020
Figure 3: Time migration of profile TM2 running along the Malaga Basin (MB, North Alboran Basin). This profile is divided in a) Western section and b) Eastern section. Main structures and seismostratigraphic units are identified. Age of the units is defined in Figure 2. Vertical exaggeration is of $\sim \mathrm{x}: 2.5$. 


\section{However, there are still uncertainties about the age of the reflections...}
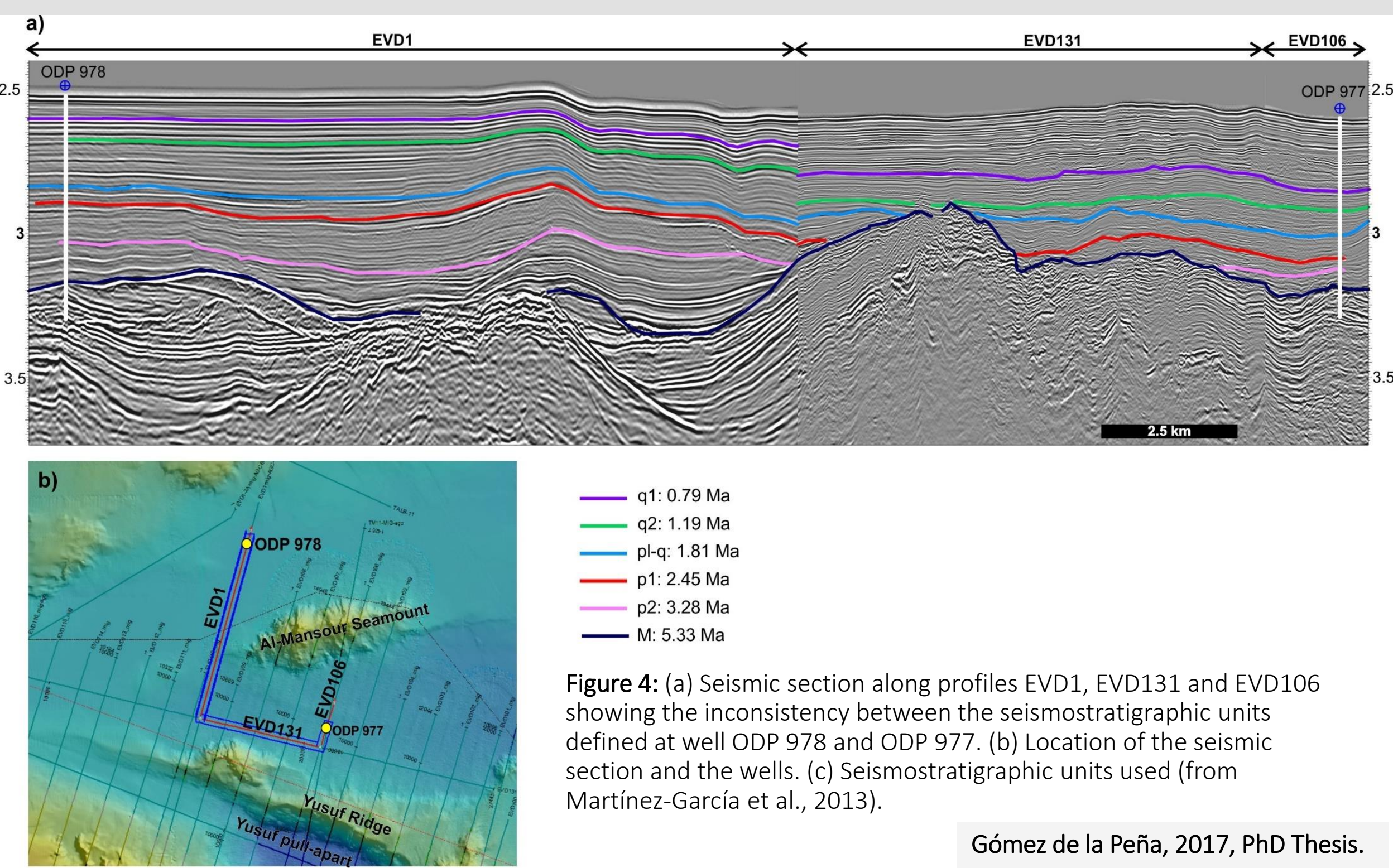

Figure 4: (a) Seismic section along profiles EVD1, EVD131 and EVD106 showing the inconsistency between the seismostratigraphic units defined at well ODP 978 and ODP 977. (b) Location of the seismic section and the wells. (c) Seismostratigraphic units used (from Martínez-García et al., 2013).

Gómez de la Peña, 2017, PhD Thesis. 
Based on the distribution of the marine sedimentary units, currently offshore and onshore, together with the distribution of crustal domains, and available information on upper mantle tomographic images and volcanic rock types distribution, we propose a refined kinematic model to explain the Latemost Oligocene to present day evolution of the westernmost Mediterranean basins.

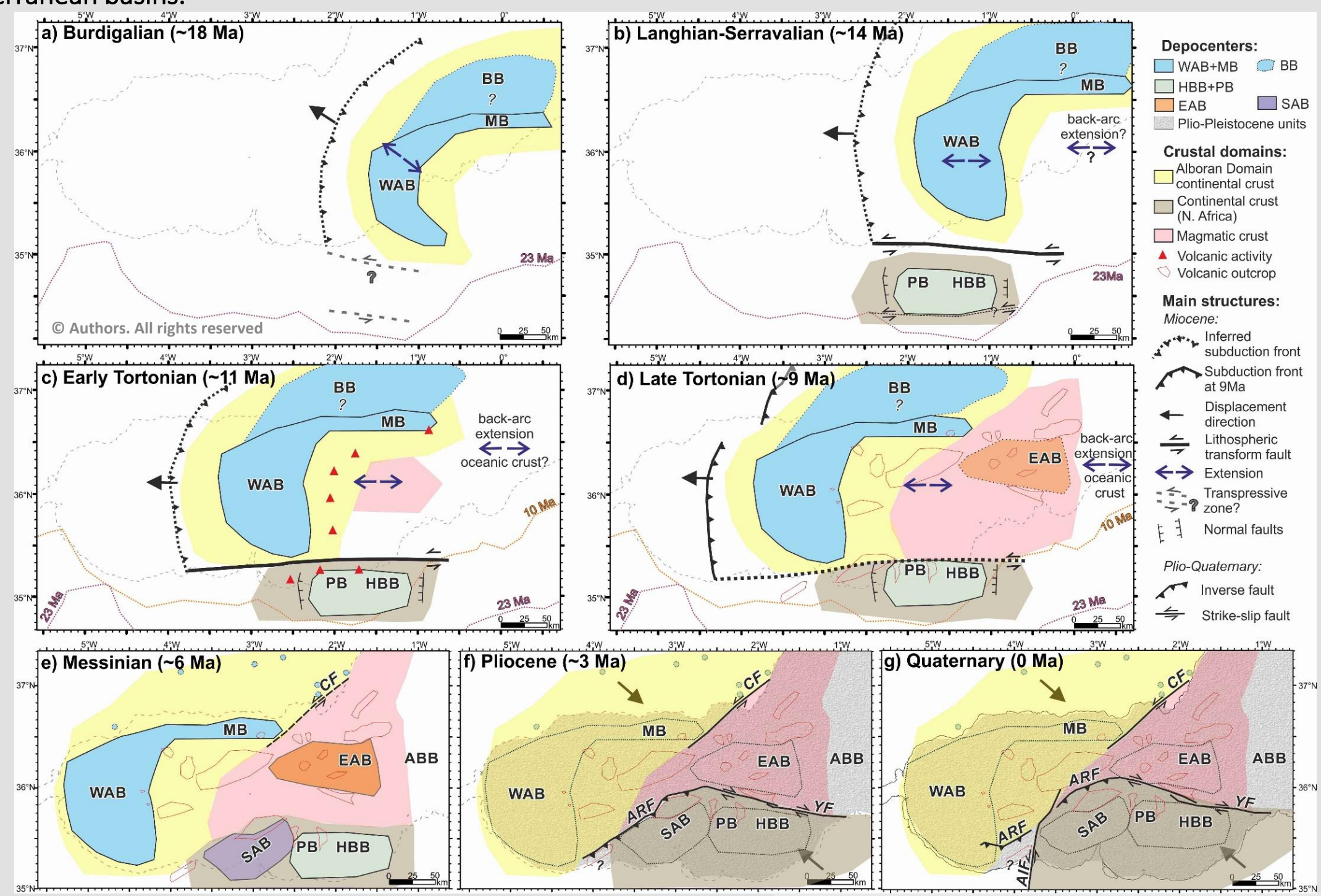

Figure 5: Kinematic model. WAB+MB: West Alboran and Malaga basins, BB: Betic Basins, HBB+PB: Habibas and Pytheas basins, EAB:

Modified from Gómez de la Peña et al., 2020, ESR, under review. East Alboran Basin, SAB: South Alboran Basin. CF: Carboneras Fault, ARF: Alboran Ridge Fault, YF: Yusuf Fault, AlF: Al-Idrissi Fault 


\section{Thank you!}

\section{References:}

Ballesteros, M., Rivera, J., Muñoz, A., Muñoz-martín, A., Acosta, J., Carbó, A., and Uchupi, E., 2008, Alboran Basin, southern Spain - Part II: Neogene tectonic implications for the orogenic float model: Marine and Petroleum Geology, v. 25, p. 75-101.

Gómez de la Peña, L., Gràcia, E., Muñoz, A., Acosta, J., Gómez-Ballesteros, M., Ranero, C.R., Uchupi, E., 2016, Geomorphology and Neogene tectonic evolution of the Palomares continental margin (Western Mediterranean). Tectonophysics, v., 689, p. 25-39, doi:10.1016/j.tecto.2016.03.009.

Gómez de la Peña, Ranero, Gràcia and Booth-Rea: The evolution of the westernmost Mediterranean basins. Under Review in "Earth-Science Reviews", 2020

Gómez de la Peña, L., 2017, The origin and tectono-sedimentary structure of the Alboran Basin. Doctoral Thesis, Universidad de Barcelona, 327 pp.

Gràcia, E., Bartolome, R., Lo lacono, C., Moreno, X., Stich, D., Martínez-Diaz, J.J., Bozzano, G., Martínez-Loriente, S., Perea, H., Diez, S., Masana, E., Dañobeitia, J.J., Tello, O., Sanz, J.L., et al., 2012, Acoustic and seismic imaging of the Adra Fault (NE Alboran Sea): in search of the source of the 1910 Adra earthquake: Natural Hazards and Earth System Science, v. 12, p. 3255-3267, doi: 10.5194/nhess-12-3255-2012.

Gràcia, E., Pallàs, R., Soto, J.I., Comas, M., Moreno, X., Masana, E., Santanach, P., Diez, S., García, M., and Dañobeitia, J., 2006, Active faulting offshore SE Spain (Alboran Sea): Implications for earthquake hazard assessment in the Southern Iberian Margin: Earth and Planetary Science Letters, v. 241, p. 734-749, doi: 10.1016/j.epsl.2005.11.009.

Martínez-García, P., Comas, M., Soto, J.I., Lonergan, L., and Watts, A. B., 2013, Strike-slip tectonics and basin inversion in the Western Mediterranean: the Post-Messinian evolution of the Alboran Sea: Basin Research, v. 25, p. 361-387, doi: 10.1111/bre.12005. 